\title{
EFFECT OF MICROWAVE RADIATION ON GROWTH AND GERMINATION OF STONE PINE (PINUS PINEA L.) SEEDLINGS
}

\author{
KUZUGUDENLI, E. \\ Department of Forestry, Suleyman Demirel University, Isparta, Turkey \\ e-mail: emrekuzugudenli@sdu.edu.tr \\ (Received $15^{\text {th }}$ Feb 2018; accepted $9^{\text {th }}$ May 2018)
}

\begin{abstract}
Highly successful afforestation applications and good performance development is linked to adoption of correct afforestation techniques, quality of seedling material, selection of appropriate origin, seed material, and treatment of seedlings. One of these treatment processes is subjecting seeds to a magnetic field. The aim of this study is to determine the effects of magnetic field on the germination of seeds and growth of seedlings of stone pine (Pinus pinea L.). For this purpose, seeds (Aydın-Koçarlı origin) were used in nursery garden beds (Isparta, Turkey) with three replications based on completely randomized design. A magnetron tube setup was used to generate a magnetic field. A $220 \mathrm{~V}$ AC magnetron tube was positioned $15 \mathrm{~cm}$ above the seed container, and 280, 336, 462, and $595 \mathrm{~W}$ output for 15,30 , and $60 \mathrm{~s}$ was applied, respectively. As a result of being subjected to the magnetic field, stone pine seeds experienced changes in seedling morphological characteristics and positive effects on seedling growth and development. It is believed that application of $280 \mathrm{~W}$ microwave of 160 micro Tesla intensity for $60 \mathrm{~s}$ could suppress live plants by encouraging quick seedling development, help seedlings benefit from water and nutrient elements in the earth, and contribute to the economy of the country by reducing development time.
\end{abstract}

Keywords: magnetic field, seed, morphological characteristics, seedling quality, afforestration

\section{Introduction}

Forests in Turkey cover 21.7 ha, or $27.6 \%$ of total area. The country has a tree value of total 1.49 billion $\mathrm{m}^{3}$ and rich bio-diversity. Half of the forest resources of the country consist of pervasive and infertile needle-leaved and broad-leaved forests. The fertiliy of our forests is low, at approximately $0.750 \mathrm{~m}^{3} / \mathrm{ha}$ per year (Urgenc, 1998). Therefore, it is necessary to fertilise pervasive forest areas with artificial rejuvenation techniques in the near future and create new forest areas with afforestation applications.

Today, in developed countries where intensive forestry techniques have been applied, determining afforestation areas only to obtain wood raw materials has been abandoned. These applications were replaced with multi-functional afforestation techniques that aim to produce raw wood material and by-products (Ilter and Ok, 2004). Through such multi-functional afforestation as used in Mediterranean and south European countries, it is obvious that such countries commonly prefer stone pine (Pinus pinea $\mathrm{L}$.) because it is more durable than other pine types, adapts to high temperatures and drought, tolerates water stress with its deep roots, provides effective protection against erosion, and has economic benefits (Ansin, 2001).

In terms of worldwide distribution of stone pine, large forests are observed in Spain, Portugal, Turkey, and Italy, as well as Greece, Syria, Lebanon, France, Yugoslavia, Montenegro, and other North Africa countries (Firat, 1943).

The stone pine is a typical Mediterranean tree, and it is one of five pine species that naturally grow in our country. Stone pine generally has a natural distribution in regions with a Mediterranean climate, which have an annual temperature average of 11.4$18.7^{\circ} \mathrm{C}$, relatively high annual precipitation average of $635.7-1288.1 \mathrm{~mm}$, and relative humidity of 58-80.8\% (Sayman et al., 2006). 
Highly successful afforestation applications and good performance development is linked with adoption of correct afforestation techniques, quality of seedling material, selection of appropriate origin, seed material, and treatment of seedlings (Urgenc, 1998). One of these treatment processes involves subjecting seeds to a magnetic field. The effects of magnetic fields on growth and development of plants and practical applications have long been discussed. Recently, some studies have indicated positive effects of magnetic fields on plant growth. Magnetic fields have been found to have positive effects on fertility and number of flowers (Matsuda et al., 1992), seed germination ratio and speed (Souza Torres et al., 1999), and earliness of flowering (Samy, 1998) of various plant types and species.

Accordingly, in afforestation applications with stone pine, which has economic and forestry importance for manufacturing of by-products, it is possible to discuss the significant effects that magnetic fields have on product yield and growth performance (Kirdar et al., 2016). Based on these facts, this study was conducted to evaluate the effects of magnetic fields on stone pine (Pinus pinea L.) seed germination and seedling growth.

\section{Materials and methods}

The material of this study consisted of seeds collected in December 2015 from naturally grown stone pine stands in the Aydın-Koçarlı region (Turkey) (37.690503 north latitude, 27.688276 east longitude, $796 \mathrm{~m}$ altitude) that showed superiority to other individuals in the stand in terms of height, diameter, and body smoothness. Before harvested seeds were planted, they were divided into 6 groups (including a control group) and subjected to magnetic fields of varying microwave power and duration via magnetron tube (Table 1).

Table 1. Properties of microwave application by the groups

\begin{tabular}{|c|c|c|c|c|}
\hline Group & $\begin{array}{c}\text { Microwave } \\
\text { intensity }(\boldsymbol{\mu} \mathbf{T})\end{array}$ & $\begin{array}{c}\text { Microwave output } \\
\text { power }(\mathbf{W})\end{array}$ & $\begin{array}{c}\text { Duration of } \\
\text { exposure (s) }\end{array}$ & $\begin{array}{c}\text { Post-Exposure seed } \\
\text { temperature }\left({ }^{\circ} \mathbf{C}\right)\end{array}$ \\
\hline 1 & 160 & 280 & 60 & 40 \\
\hline 2 & 192 & 336 & 30 & 60 \\
\hline 3 & 192 & 336 & 60 & 78 \\
\hline 4 & 264 & 462 & 15 & 94 \\
\hline 5 & 340 & 595 & 15 & 108 \\
\hline \multicolumn{5}{|r}{ Control Group } \\
\hline
\end{tabular}

A magnetron tube setup was used for generating the magnetic field. A 220V AC magnetron tube was positioned $15 \mathrm{~cm}$ above the seed container, and 280, 336, 462, and $595 \mathrm{~W}$ output power was applied for 15, 30, and $60 \mathrm{~s}$. Seeds were not applied at high output powers (462 and $595 \mathrm{~W}$ ) for 30 and $60 \mathrm{~s}$ due to overheating. The frequency of the microwave was $2450 \mathrm{MHz}$.

Seeds were planted in 2016 in the Suleyman Demirel University-Yenisarbademli Vocational School application nursery garden beds with three replications based on completely randomized design. The nursery garden field has a semi-continental climate in a Mediterranean climate transition area and an altitude of $1178 \mathrm{~m}$. Annual average temperature was $11.2^{\circ} \mathrm{C}$, and annual average precipitation was $727.2 \mathrm{~mm}$. The $0-30 \mathrm{~cm}$ 
deep planting bed on the trial's planting parcel was $57.9 \%$ sand, $23.3 \%$ silt, and $18.8 \%$ clay with a silty loam texture (Figure 1).

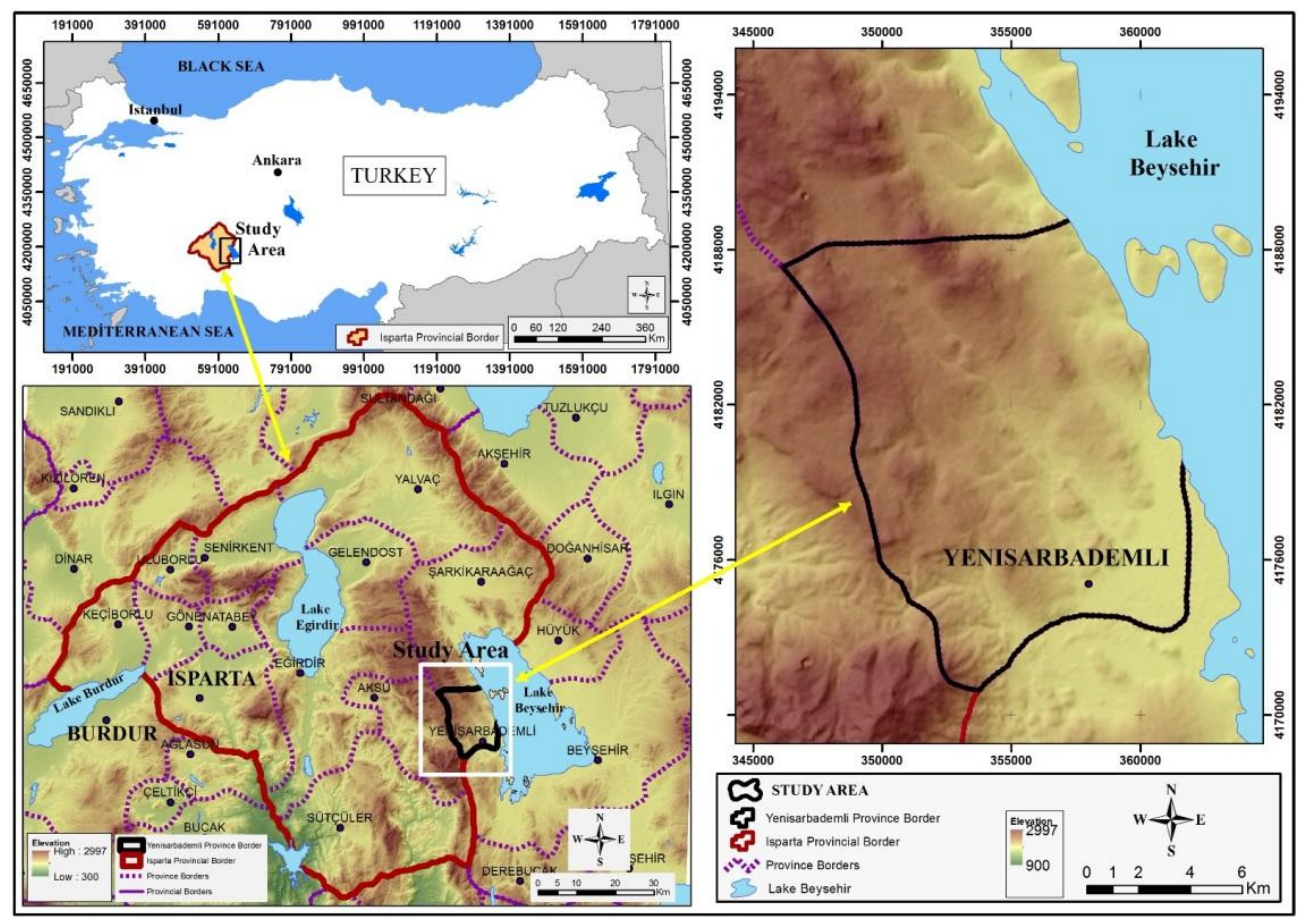

Figure 1. Study area

Germinated seeds were counted once every 3-4 days starting from the first germination. Germination percentage (GP) was calculated for each treatment. The formula used for calculating the germination percentage is as follows (Eq. 1):

$$
G P=\frac{\sum m i}{N} x 100
$$

with ni as the number of seeds germinated on the $\mathrm{i}^{\text {th }}$ day, and $\mathrm{N}$ indicating the total number of seeds in the germination experiment.

During the 1-year growth period, routine seedling growth applications of weeding, hoeing, and irrigation were applied. Seedling removal was conducted without harming the roots of seedlings in the fall season when growth and development was completed. After removing the seedlings, they were placed in a bucket with water without harming roots or offshoots and were monitored carefully. Later, the shoot height $(\mathrm{cm})$, shoot fresh weight $(\mathrm{g})$, root collar diameter $(\mathrm{mm})$, tap root length $(\mathrm{cm})$, and root fresh weight (g) of seedlings were measured. For this purpose, a total of 540 seedlings, or 90 seedlings in each group, were measured. Heights were measured with a ruler with $1 \mathrm{~mm}$ sensitivity, weights were measured with a sensitive scale, and root collar diameters were measured with an electronic calliper with $0.01 \mathrm{~mm}$ sensitivity.

SPSS 20.0 Windows package program was used for comparing the measured morphological and physiological characteristics, and variance analysis and the Duncan test were applied. 


\section{Results}

Germinations were recorded to measure the germination percentage of planted seeds. Germinations were completed at the end of 1 month. First germination was observed in seeds in the control group, which had the highest germination percentage (61\%). Based on this information, after the 1-month period, the number of germinated seeds was divided by the total number of planted seeds and germination percentages were calculated (Figure 2).

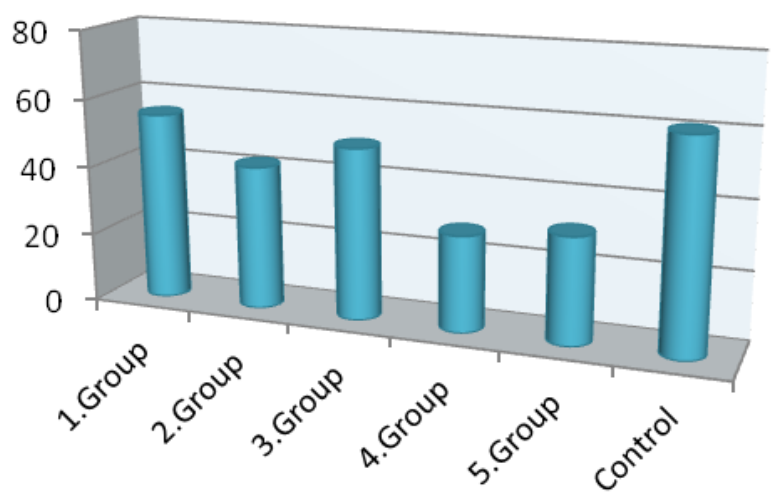

Figure 2. Germination percentage (\%) of groups

Based on variance analysis of seedling morphological characteristic and following Duncan test results, it was shown that magnetic fields have statistically significant ( $\mathrm{p}<$ $0.001)$ effects on shoot height (SH), shoot fresh weight (SFW), root collar diameter (RCD), tap root length (TRL), and root fresh weight (RFW) of stone pine. Average values, standard deviation, $F$ value, importance level, and classification of groups are given in Table 2. When groups were analyzed in terms of seedling morphological characteristics, seedlings in group 1 had higher average values compared to the other groups, whereas most of groups 3, 4, and 5 had the lowest values.

According to variance analysis results, it was determined that in terms of morphological characteristics, the highest $\mathrm{F}$ value was observed in tap root length and the lowest $F$ value was observed in root fresh weight, where all groups were differentiated with the same significance level $(\mathrm{p}<0.001)$ (Table 2).

Table 2. Variance analysis results of groups by morphological characteristics (mean and standard error)

\begin{tabular}{|l|l|l|l|l|l|}
\hline Group & RCD $(\mathbf{m m})$ & $\mathbf{S H}(\mathbf{c m})$ & TRL $(\mathbf{c m})$ & SFW $($ gr $)$ & RFW(gr) \\
\hline Control & $2.39+0.1 \mathrm{~b}$ & $12.2+0.5 \mathrm{~b}$ & $21.6+1.1 \mathrm{~b}$ & $21.4+2.3 \mathrm{~b}$ & $4.5+0.3 \mathrm{~b}$ \\
\hline 1 & $2.84+0.2 \mathrm{a}$ & $14.9+0.6 \mathrm{a}$ & $24.9+0.6 \mathrm{a}$ & $28.9+2.9 \mathrm{a}$ & $5.7+0.5 \mathrm{a}$ \\
\hline 2 & $2.04+0.1 \mathrm{c}$ & $13+0.8 \mathrm{ab}$ & $19.8+1.3 \mathrm{~b}$ & $15.7+1.5 \mathrm{c}$ & $3.8+0.5 \mathrm{~cd}$ \\
\hline 3 & $2.44+0.1 \mathrm{~b}$ & $11.7+0.8 \mathrm{~b}$ & $24.3+0.4 \mathrm{a}$ & $21.3+1.9 \mathrm{~b}$ & $4.3+0.4 \mathrm{bcd}$ \\
\hline 4 & $2+0.1 \mathrm{c}$ & $13.7+0.5 \mathrm{ab}$ & $16.7+1.2 \mathrm{c}$ & $15.4+0.9 \mathrm{c}$ & $2.9+0.3 \mathrm{~d}$ \\
\hline 5 & $2.24+0.1 \mathrm{bc}$ & $8.3+0.5 \mathrm{c}$ & $16+0.6 \mathrm{c}$ & $19.9+0.6 \mathrm{bc}$ & $4+0.3 \mathrm{bc}$ \\
\hline $\begin{array}{l}\text { Significance } \\
\text { level }\end{array}$ & $\mathrm{P}<0.001$ & $\mathrm{P}<0.001$ & $\mathrm{P}<0.001$ & $\mathrm{P}<0.001$ & $\mathrm{P}<0.001$ \\
\hline $\mathrm{F}$ & & 11.1 & 16.9 & 7.01 & 6.16 \\
\hline
\end{tabular}


Stone pine seedlings were classified according to shoot height and root collar diameter as specified in the Turkish Standards Institute's Seedling Standards (TSE, 1988). Based on this classification, group 1 had the highest percentage (92\%) and group 5 had the lowest percentage (4\%) among 1st-grade seedlings in terms of shoot height. For root collar diameter, group 1 and group 3 had the highest values (both 100\%) and group 4 had the lowest value (52\%) among 1st-grade seedlings (Table 3).

Table 3. Distribution to quality classes of shoot height and root collar diameter based on TSI Seedling Standards

\begin{tabular}{|c|c|c|c|c|c|c|c|c|}
\hline & \multicolumn{2}{|c|}{ TSI Seedling Standards (1988) } & \multicolumn{6}{|c|}{ Distribution to Quality Classes (\%) of Group } \\
\hline & Class & Range & 1 & 2 & 3 & 4 & 5 & Control \\
\hline \multirow{3}{*}{$\begin{array}{l}\text { Shoot } \\
\text { Height (SH) }\end{array}$} & I & $\mathrm{SH}>12 \mathrm{~cm}$ & 92 & 64 & 48 & 68 & 4 & 70 \\
\hline & II & $10 \mathrm{~cm}<\mathrm{SH}<12 \mathrm{~cm}$ & 8 & 20 & 22 & 22 & 32 & 22 \\
\hline & Cull & $\mathrm{SH}<12 \mathrm{~cm}$ & 0 & 16 & 30 & 10 & 64 & 8 \\
\hline \multirow{2}{*}{$\begin{array}{l}\text { Root Collar } \\
\text { Diameter } \\
(\mathrm{RCD})\end{array}$} & I & $\mathrm{RCD}>2 \mathrm{~mm}$ & 100 & 60 & 100 & 52 & 98 & 93 \\
\hline & Cull & $\mathrm{RCD}<2 \mathrm{~mm}$ & 0 & 40 & 0 & 48 & 2 & 7 \\
\hline
\end{tabular}

\section{Discussion and conclusions}

In this study, the effects of magnetic fields on certain morphological characteristics of germinating seedling stone pine trees were investigated. Stone pine seeds were subjected to microwaves of different power settings (280, 336, 462, and $595 \mathrm{~W})$ and durations $(15,30$, or $60 \mathrm{~s})$ and were planted along with control group seeds. At the end of one vegetation period, the germination status of seeds and shoot height, shoot fresh weight, root collar diameter, tap root length, and root fresh weight of $1+0$ seedlings were investigated.

Based on the findings of this study, it was determined that magnetic field application influenced the development of seedlings with $99.9 \%$ statistical confidence. It was determined that seeds subjected to a magnetic field had a lower germination percentage compared to the control group. A similar study that investigated the effects of magnetic fields on germination of mung bean plants indicated that certain magnetic field groups (30, 40, and F50 Hz) had a lower germination percentage compared to the control group (Huang and Wang, 2008).

When seeds are subjected to microwave radiation, the microwaves first pass through the cell wall and later are absorbed by the water molecules in the seed. As a result, tissues containing water heat significantly, and cytoplasm collapses the cell wall and leaks out. Furthermore, due to excessive heating, proteins in the seed may denature and lose functionality. Therefore, it is believed that certain seeds subjected to microwave energy were deformed and had a lower germination percentage compared to the control group (Brodie et al., 2012).

It is also believed that this negative effect is due to increased gibberellin and cytokinin synthesis or activity. In particular, gibberellin has a high ratio in developing seeds. It plays a significant role in controlling and stimulating seed germination. Gibberellin stimulates enzymes for germination of seeds and the $\alpha$-amylase enzyme that carries those enzymes from embryo to endosperm to convert starch to sugar for energy supply. Cytokinin has a role in cell multiplication and stimulation of cell expansion 
(Hartmann et al., 1997; Hilhorst and Karssen, 1992). For these reasons, gibberellin and cytokinin may cause lower a germination percentage in test groups compared to the control group.

One-way variance analysis (ANOVA) was conducted to test whether there was significant difference between groups' averages in seedling morphological characteristics. Test results indicated that there was a statistically significant difference between groups $(\mathrm{p}<0.001)$. The Duncan test was applied to determine which group $(\mathrm{s})$ caused such difference. Test results indicated that the magnetic field had a statistically significant effect $(\mathrm{p}<0.001)$ on shoot height, shoot fresh weight, root collar diameter, tap root length, and root fresh weight of stone pine. When groups were analysed in terms of all morphological characteristics, the highest average of germinated seeds was identified in the group that was subjected to $280 \mathrm{~W}$ microwave energy with 160 micro Tesla intensity for 60 seconds.

Another study that investigated the relationship between certain magnetic field applications and development of stone pine indicated that a magnetic field with $9.42 \mathrm{mT}$ intensity had positive effects on development of seedlings (Kirdar et al., 2016). Similar results were obtained for different plants, such as by Matsuda et al. (1992) for strawberry (Fragaria sp.); Vashisth and Nagarajan (2008) for chickpea (Cicer arietinum L.); Souza Torres et al. (1999) and Martinez et al. (2009) for tomato (Lycopersicon esculentum Mill.); Cakmak et al. (2010) for wheat (Triticumaestivum L. cv. Bezostaya) and bean (Phaseolus vulgaris L. cv. Gina); Tanvir et al. (2012) for white siris (Albizia procera Benth.); Racuciu (2012) for corn (Zea mays L.); and Cramariuc et al. (2005) for potato.

Magnetic fields may increase seedling development in particular due to effects on auxin, cytosine, and gibberellin metabolism. The most important effect of cytokinin in plants is in cell multiplication, and the most important effect of auxin and gibberellin is in increasing cell elongation (Jansen, 1982; Arteca, 1996). Increased synthesis or activity of auxin, cytokinin, and gibberellin may cause an increase in shoot height, shoot fresh weight, root collar diameter, tap root length, and root fresh weight of seedlings.

When groups were analysed, the highest average in terms of morphological characteristics was found in seedlings in group 1. It is believed that the lower seedling morphological characteristics of other groups was caused by an increase in seed temperature in line with increased magnetic field intensity and duration (Table 1). Similarly, Kazanci (2014) investigated the effects of high temperature on seed germination and found that among 37 of 71 taxa, high temperature $\left(100-140^{\circ} \mathrm{C}\right)$ had negative effects on seed germination.

As a result, the magnetic field applied to stone pine seeds had effects on seedling morphological characteristics and positive effects on seedling growth and development. In this sense, in afforestation applications with stone pine, which has economic and forestry importance for manufacturing of by-products, it is believed that application of $280 \mathrm{~W}$ microwaves with an $160 \mu \mathrm{T}$ intensity for $60 \mathrm{~s}$ could suppress live plants by developing seedlings quickly, help seedlings to benefit from water and nutrient elements in the earth, and contribute to the economy of the country by reducing development time. Seeds should not applied at high output power (minimum $462 \mathrm{~W}$ ) for more than $15 \mathrm{~s}$ due to overheating. It is recommended to applied at low output powers for more than $60 \mathrm{~s}$ for further studies. A study that investigated the relationship between certain magnetic field applications and development of stone pine indicated that a magnetic field (9.42 mT intensity) with $45 \mathrm{~m}$ had positive effects on development of 
seedlings (Kirdar et al., 2016). Similarly, Vashisth and Nagarajan (2010) investigated the effects of magnetic field applications on sunflower (Helianthus annuus L.) seeds germination and found that 50 and $200 \mathrm{mT}$ for $2 \mathrm{~h}$ exposure yielded superior results.

Studies of the effect of the microwave on the seeds of the forest trees are very limited. So it is thought that it will lead similar studies to be done in this field.

\section{REFERENCES}

[1] Ansin, R. (2001): Tohumlu Bitkiler Gymnospermae (Acik Tohumlular) (in Turkish). Karadeniz Technical University Publishing, No: 122, Forest Faculty Publishing, No: 15. ISBN 975-6983-16-7, Trabzon.

[2] Arteca, R.N. (1996): Plant Growth Substances, Principles and Applications. - Chapman \& Hall, New York, 260s.

[3] Brodie, G. (2007): Simultaneous heat and moisture diffusion during microwave heating of moist wood. - Applied Engineering in Agriculture 23(2):179-187.

[4] Cakmak, T., Dumlupinar, R., Erdal, S. (2010): Acceleration of germination and early growth of wheat and bean seedlings grown under various magnetic field and osmotic conditions. - Bioelectromagnetics 31(2): 120-129.

[5] Cramariuc, R., Donescu, V., Popa, M., Cramariuc, B. (2005): The biological effect of the electrical field treatment on the potato seed: agronomic evaluation. - Journal of Electrostatics 63(6-10): 837-846.

[6] Firat, F. (1943): Fistikcami Ormanlarimizda Meyve ve Odun verimi Bakimindan Arastirmalar ve Bu ormanlarin Amenajman Esaslari (in Turkish). - Higher Agricultural Institute Publishing, No: 141.

[7] Hartmann, H. T., Kester, D. E., Davies, F. T. (1997): Principles of propagation by seed. Plant Propagation-Principles and Practices. - Prentice Hall of India Private Limited, New Delhi, 177-194.

[8] Hilhorst, H. W. M., Karssen, C. M. (1992): Seed dormancy and germination: the role of abscisic acid and gibberellins and the importance of hormone mutants. - Plant growth regulation 11(3): 225-238.

[9] Huang, H. H., Wang, S. R. (2008): The effects of inverter magnetic fields on early seed germination of mung beans. - Bioelectromagnetics 29(8): 649-657.

[10] Jansen, H. (1982): Bahce ziraatinda buyutucu ve engelleyici maddelerin kullanilmasi ve onemi (in Turkish). - Ataturk University Publishing, No: 599, 130p, Erzurum

[11] Kazanci, D. D. (2014): Determination of Post Fire Germination Properties of Mediterranean Plants. - Hacettepe University, Biology Department, 85p, Ankara (Unpublished Master Thesis)

[12] Kirdar, E., Yücedag, C., Balaban, B. (2016): The Effects of Magnetic Field on Germination of Seeds and Growth of Seedlings of Stone Pine. - Journal of Forests 3(1): $1-6$.

[13] Ilter, E., Ok, K. (2004): Ormancilik ve Orman Endustrisinde Pazarlama Ilkeleri ve Yonetimi (Ornek Olaylarla) (in Turkish). - Form Ofset Publish, ISBN 975-96967.

[14] Martinez, E., Carbonell, M. V., Florez, M., Amaya, J. M., Maqueda, R. (2009): Germination of tomato seeds (Lycopersicon esculentum L.) under magnetic field. International Agrophysics 23(1): 45-49.

[15] Matsuda, T., Asou, H., Kobayashi, M., Yonekura, M. (1992): Influences of magnetic fields on growth and fruit production of strawberry. - In: II International Strawberry Symposium 348, Sepetember 13-18, Maryland, USA, pp. 378-380.

[16] Racuciu, M. (2012): Influence of extremely low frequency magnetic field on assimilatory pigments and nucleic acids in Zea mays and Curcubita pepo seedlings. - Romanian Biotechnological Letters 17(5): 7663. 
[17] Samy, C. G. (1998): Magnetic seed treatment. I. Influence on flowering, siliqua and seed characters of cauliflower. - Orissa Journal of Horticulture 26(2): 68-69.

[18] Sayman, M., Akbin, G., Kilci, M. (2006): Fistik cami (Pinus pinea L.) kurak ve yarikurak bolge Agaclandirmalari icin uygun bir turmudur (in Turkish). - Evaluation Workshop in the Semi Arid Regions Made in Turkey Afforestation and Erosion Control Applications, November 7-10, 2006, Turkey, pp.343-352.

[19] Souza Torres, A. D., Porras Leon, E., Casate Fernandez, R. (1999): Effect of magnetic treatment of tomato seeds (Lycopersicon esculentum Mill) on germination and seedling growth. Investigacion Agraria. - Produccion y Proteccion Vegetales (Espana).

[20] Tanvir, M. A., HAQ, Z. U., Hannan, A., Nawaz, M. F., Siddiqui, M. T., Shah, A. (2012): Exploring the growth potential of Albizia procera and Leucaena leucocephala as influenced by magnetic fields. - Turkish Journal of Agriculture and Forestry 36(6): 757763.

[21] TSE, (1988): İğne Yapraklı Ağaç Fidanları Standardı (in Turkish). - Publications of Turkish Standards Institute, TS 2265, Ankara.

[22] Urgenc, S. (1998): Agac ve Sus Bitkileri Fidanlik ve Yetistirme Teknigi (in Turkish). Istanbul University. Forest Faculty Publishing, No: 418

[23] Vashisth, A., Nagarajan, S. (2008): Exposure of seeds to static magnetic field enhances germination and early growth characteristics in chickpea (Cicer arietinum L.). Bioelectromagnetics 29(7): 571-578.

[24] Vashisth, A., Nagarajan, S. (2010): Effect on germination and early growth characteristics in sunflower (Helianthus annuus) seeds exposed to static magnetic field. Journal of Plant Physiology 167(2): 149-156. 